Article

\title{
Combustion, Performance, and Emission Evaluation of a Diesel Engine with Biodiesel Like Fuel Blends Derived from a Mixture of Pakistani Waste Canola and Waste Transformer Oils
}

\author{
Muhammad Qasim * (D), Tariq Mahmood Ansari and Mazhar Hussain \\ Institute of Chemical Sciences, Bahauddin Zakariya University, Multan 60800, Pakistan; \\ drtariq2000@gmail.com (T.M.A.); hmz14@yahoo.com (M.H.) \\ * Correspondence: drqasimmazari@gmail.com
}

Received: 12 June 2017; Accepted: 12 July 2017; Published: 18 July 2017

\begin{abstract}
The aim of this work was to study the combustion, performance, and emission characteristics of a $5.5 \mathrm{~kW}$ four-stroke single-cylinder water-cooled direct-injection diesel engine operated with blends of biodiesel-like fuel (BLF15, BLF20 \& BLF25) obtained from a 50:50 mixture of transesterified waste transformer oil (TWTO) and waste canola oil methyl esters (WCOME) with petroleum diesel. The mixture of the waste oils was named as biodiesel-like fuel (BLF). The engine fuelled with BLF blends was evaluated in terms of combustion, performance, and emission characteristics. FTIR analysis was carried out to know the functional groups in the BLF fuel. The experimental results revealed the shorter ignition delay and marginally higher brake specific fuel consumption (BSFC), brake thermal efficiency (BTE) and exhaust gas temperature (EGT) values for BLF blends as compared to diesel. The hydrocarbon $(\mathrm{HC})$ and carbon monoxide $(\mathrm{CO})$ emissions were decreased by $10.92-31.17 \%$ and $3.80-6.32 \%$, respectively, as compared to those of diesel fuel. Smoke opacity was significantly reduced. FTIR analysis has confirmed the presence of saturated alkanes and halide groups in BLF fuel. In comparison to BLF20 and BLF25, the blend BLF15 has shown higher brake thermal efficiency and lower fuel consumption values. The $\mathrm{HC}, \mathrm{CO}$, and smoke emissions of BLF15 were found lower than those of petroleum diesel. The fuel blend BLF15 is suggested to be used as an alternative fuel for diesel engines without any engine modification.
\end{abstract}

Keywords: waste transformer oil; waste canola oil; combustion; performance; emissions; diesel engine

\section{Introduction}

Global warming has been intensified over the past three decades because of the drastic increase in greenhouse gases (GHG) generated by fossil fuels. Resulting from global warming, the abnormal climate change is the causative agent for phenomena like intense heat, sudden rainstorms, typhoons, and floods. The mitigation of GHG emissions and change in climate behavior has become a primary motivation for bio-fuels research. Moreover, growing concerns of environmental contamination due to excessive use of fossil fuels has stimulated the scientists of the world to search for more environmentally-friendly, feasible, and renewable fuels. In this connection bio-fuels, like biodiesel, have received a remarkable attention to be used as alternatives for diesel engines [1,2].

Generally, biodiesels derived from waste vegetable oils are economically more feasible to be used as a replacement for diesel fuel. Additionally, they emit less pollutant and GHG emissions. Mostly, diesel engines are used in agricultural applications, and industrial and urban transportation purposes. Despite their noise and vibration disadvantages, they have a large power output, high thermal efficiency, and are highly reliable. However, in comparison to gasoline engines, diesel engines 
emits relatively more nitrogen oxide $\left(\mathrm{NO}_{x}\right)$ and particulate matter $(\mathrm{PM})$. Moreover, the regulations for $\mathrm{NO}_{x}$ and $\mathrm{PM}$ emissions (smoke opacity) from diesel have been strengthened and their emissions are important environmental issues [3-8].

In Pakistan, there are negligible petroleum reserves. Thus, the country imports petroleum fuel every year from international markets and spends a very large amount of its foreign currency against fuel import bills; this action makes the country economically feeble. Pakistan imports petroleum products from the Middle East. In Pakistan, there is a sufficient amount of unused waste transformer oil (WTO), a big source of energy but, unfortunately, this golden waste oil is dumped and discarded every year.

Generally, the main use of transformer oil in the electrical transformers is for the purpose of insulation. After a long-term usage, changes occur in the physicochemical properties of the oil, which is then designated as waste oil and is replaced. Poor handling and improper disposal of this waste transformer oil causes environmental pollution as it contains polychlorinated biphenyls (PCBs) which are cancer-causing, and other heavy metals, which might pollute the soil. As per the literature review, the studies on the patients exposed to PCBs indicated the potential impact on liver, gastrointestinal tract, and urinary tract cancers. Apart from respiratory tract irritation, blood changes, fatigue, and depression have been reported. PCBs usually reach the environment as a result of improper waste transformer oil disposal. Elevated levels of some metals harmful to human health, like iron, copper, aluminum, lead, tin, silver, and zinc, are found in waste transformer oils due to their presence in the materials of the transformer components. Iron can be found in the transformer core and tank, lead in soldered connectors and joints, copper can be found in transformer windings, aluminum in ceramic insulators and coils, and tin, silver, and zinc in some peripheral components [9-11]. Many transformers are located at shopping centers and populated areas where, if serious spills of the oil occur, it contaminates the soil and waterways and is a serious threat to public health [12,13].

Disposal of waste transformer oil into land or water causes environmental problems. To avoid these problems, reutilization of the waste oil is inevitable. Thus, it is very much necessary to reuse this dangerous waste oil in an environmentally-friendly way as the previous studies indicate that WTO could be used as a diesel substitute [14]. By re-utilizing waste transformer oil in a proper manner, Pakistan can minimize the burden over the foreign exchequers by reducing the import of petroleum products from other countries and reduce environmental problems.

Biodiesel is an eco-friendly and most prominent fuel resource as it emits less pollutant emissions as compared to petroleum diesel. In addition to these benefits, biodiesel increases the engine's lubricity due to a higher viscosity and contributes to environmental sustainability $[15,16]$. Dumping of waste vegetable oils is an environmental problem. These waste oils are mostly dumped into bodies of water, which disturb the ecosystem by forming an oily layer on the surface of the water, thereby reducing the oxygen exchange. Furthermore, disposal into the sewerage systems jams the flowing pipes, producing offensive smells and overflowing of sewer pipelines might cause different types of fatal diseases. Therefore, recovering and reusing waste vegetable oils is the need of the time [17].

A large amount of waste energy sources are discharged without utilizing the energy contents available in the waste disposals. Many researchers have worked on alternative fuel resources, such as alcohols, biodiesel, and plastic liquids to be used as alternative fuels for diesel engines [18-20]. Many experiments have been performed on the utilization of tire oil and waste lubricating oil as an engine fuel substitute. In this regard Mani et al. [21] demonstrated the effective utilization of waste plastic oil, a renewable and biodegradable fuel produced by the crackling process in adiesel engine. The study reports on reduction in $\mathrm{NO}_{x}$ (oxides of nitrogen), $\mathrm{CO}$ (carbon monoxide), and UHC (un-burnt hydrocarbon) emissions at retarded injection timing of $14{ }^{\circ} \mathrm{CA}$ (crank angle) BTDC (before top dead center). Waste engine oil reutilization in diesel engines by pyrolytic distillation methods were studied [22-25].

Consequently, the experimental investigation of it in a diesel engine revealed an increase in engine torque and BTE, while $\mathrm{CO}$ and $\mathrm{NO}_{x}$ emissions were shown to be reduced. However, very few attempts 
have been made on the usage of waste transformer oil as an engine fuel substitute. Behera et al. [26] directly blended waste transformer oil with diesel fuel without any pretreatment and used it as a fuel in engine; they observed a decrease in smoke density at maximum brake power.

The aim of the present research was to investigate diesel engine combustion, performance, and exhaust emissions by using biodiesel-like fuel blends (BLF15, BLF20, and BLF25) derived from a mixture of pretreated (transesterified) waste transformer oil and waste canola oil as fuel substitutes for diesel engines. The other properties, such as density, viscosity, lower heating value (calorific value), flash point, pour point, acid value, water contents, and Fourier transform infra-red (FTIR) spectroscopy were studied.

\section{Materials and Methods}

\subsection{Samples Collection}

Three liters of waste transformer oil sample was collected from the hydro-electric power station located at Multan, Pakistan, as per standard sampling procedures. Three liter samples of waste cooking oil was collected from arestaurant (Eaton Bar BQ Restaurant) located in Multan, Pakistan, which serves mostly fast foods. The cooking oil used was known to be canola oil. The samples were pretreated, transesterified, and blended with petroleum diesel at different concentrations as shown in Table 1.

Table 1. Composition of BLF and its blends.

\begin{tabular}{cccccc}
\hline \multirow{2}{*}{ Sr. No. } & \multirow{2}{*}{ Fuel Type } & \multicolumn{2}{c}{ BLF Composition } & \multicolumn{2}{c}{ BLF-Diesel Blends Description } \\
\cline { 3 - 6 } & & TWTO Volume & WCOME Volume & BLF Volume & Diesel Volume \\
\hline \multirow{2}{*}{1} & Diesel & - & - & $0 \mathrm{~mL}$ & $1000 \mathrm{~mL}$ \\
2 & (BLF0) & & $500 \mathrm{~mL}$ & $1000 \mathrm{~mL}$ & $0 \mathrm{~mL}$ \\
3 & BLF100 & $500 \mathrm{~mL}$ & $500 \mathrm{~mL}$ & $150 \mathrm{~mL}$ & $850 \mathrm{~mL}$ \\
4 & BLF15 & $500 \mathrm{~mL}$ & $500 \mathrm{~mL}$ & $200 \mathrm{~mL}$ & $800 \mathrm{~mL}$ \\
5 & BLF20 & $500 \mathrm{~mL}$ & $500 \mathrm{~mL}$ & $250 \mathrm{~mL}$ & $750 \mathrm{~mL}$ \\
\hline
\end{tabular}

\subsection{Transesterification Process}

$\mathrm{NaOH}(3.70 \mathrm{~g})$ was dissolved in $200 \mathrm{~mL}$ methanol in a $500 \mathrm{~mL}$ conical flask to obtain a sodium methoxide solution. The waste cooking oil was first heated at an elevated temperature $\left(110^{\circ} \mathrm{C}\right)$ to remove the moisture content and then cooled to $50{ }^{\circ} \mathrm{C}$. One kilogram of this preheated waste vegetable oil was poured into the sodium methoxide solution. After this, the mixture was kept on a hot plate with a magnetic stirrer at $55^{\circ} \mathrm{C}$ for about $70 \mathrm{~min}$ to complete the transesterification reaction. Then, the flask cover was removed and heating was continued for half an hour in order to evaporate the extra methyl alcohol. Then the mixture was removed from the hot plate and allowed to cool, then was transferred to the separating funnel and left in the funnel in a vertical position over night. Two different liquid phases appeared inside the funnel. The top layer was biodiesel and the bottom layer was glycerin. The biodiesel, so prepared, was separated out and further purified by washing with de-ionized water ( $30 \%$ by volume of biodiesel) and dried with $\mathrm{Na}_{2} \mathrm{SO}_{4}$ followed by filtration to obtain pure biodiesel (waste cooking oil methyl esters). After preparation of biodiesel its blends were prepared as shown in Table 1, for further analysis.

The waste transformer oil was first filtered to remove suspended particles, dust, gum-type materials, metal particles, and other impurities, then subjected to the transesterification process as per the procedures mentioned above so as to reduce its viscosity level.

\subsection{FTIR Analysis}

An FTIR spectrometer, Spectrum Two (Perkin Elmer, Waltham, MA, USA), was used for FTIR analysis. Figures 1 and 2 represent the scanned FTIR spectra of conventional diesel and BLF (the mixture 
of transesterified waste canola and waste transformer oils), respectively. The frequency ranges, bond types, and family for petroleum diesel and transesteried waste oils (BLF) are given in Table 2. In the case of petroleum diesel fuel, the strong absorbance peaks at 2922.03 and $2852.59 \mathrm{~cm}^{-1}$ represent $\mathrm{C}-\mathrm{H}$ stretching. The peak at $1459.09 \mathrm{~cm}^{-1}$ represents $\mathrm{C}-\mathrm{H}$ bending. These are the evidences which confirm the presence of alkanes. For biodiesel-like fuel (BLF), the strong absorbance peaks at 2922.87 and $2853.26 \mathrm{~cm}^{-1}$ represent $\mathrm{C}-\mathrm{H}$ stretching. The peaks at 1458.58 and $722.02 \mathrm{~cm}^{-1}$ represent $\mathrm{C}-\mathrm{H}$ bending and $\mathrm{C}-\mathrm{H}$ out of plane bending, respectively, and these absorbance peaks indicate the presence of alkanes. The presence of $\mathrm{C}-\mathrm{H}$ group (hydrocarbons) indicates that the liquids have a potential to be used as fuels. Similar FTIR results for transformer oil have been reported by Prasanna et al. [27].

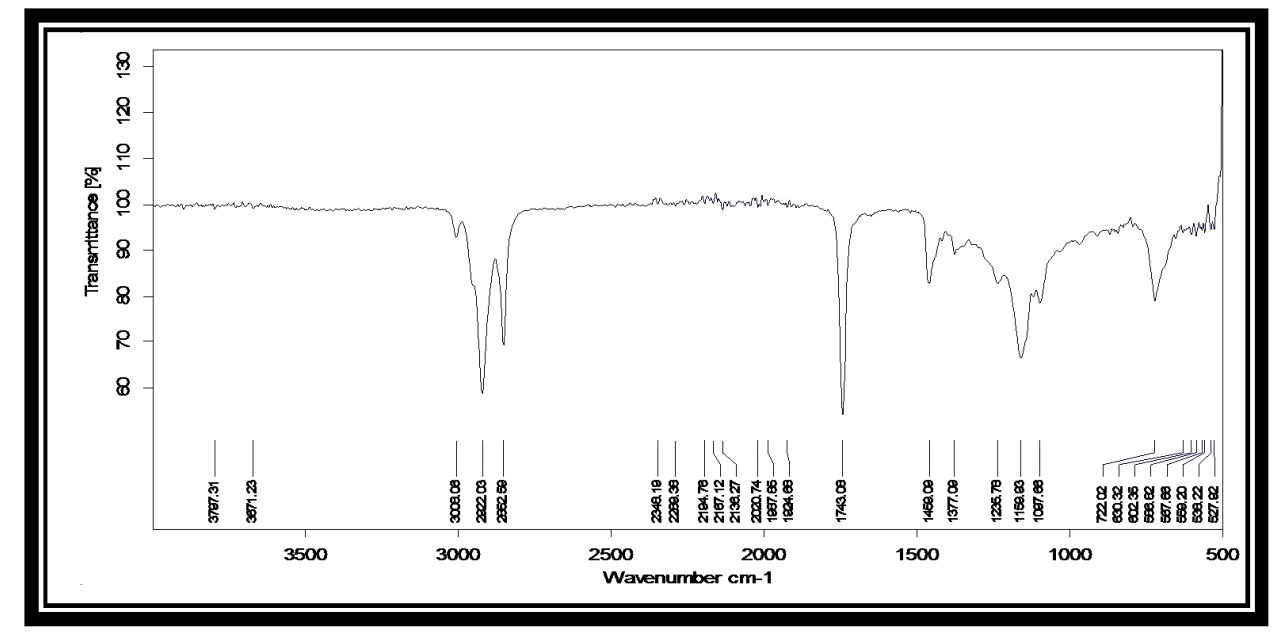

Figure 1. FTIR of diesel fuel.

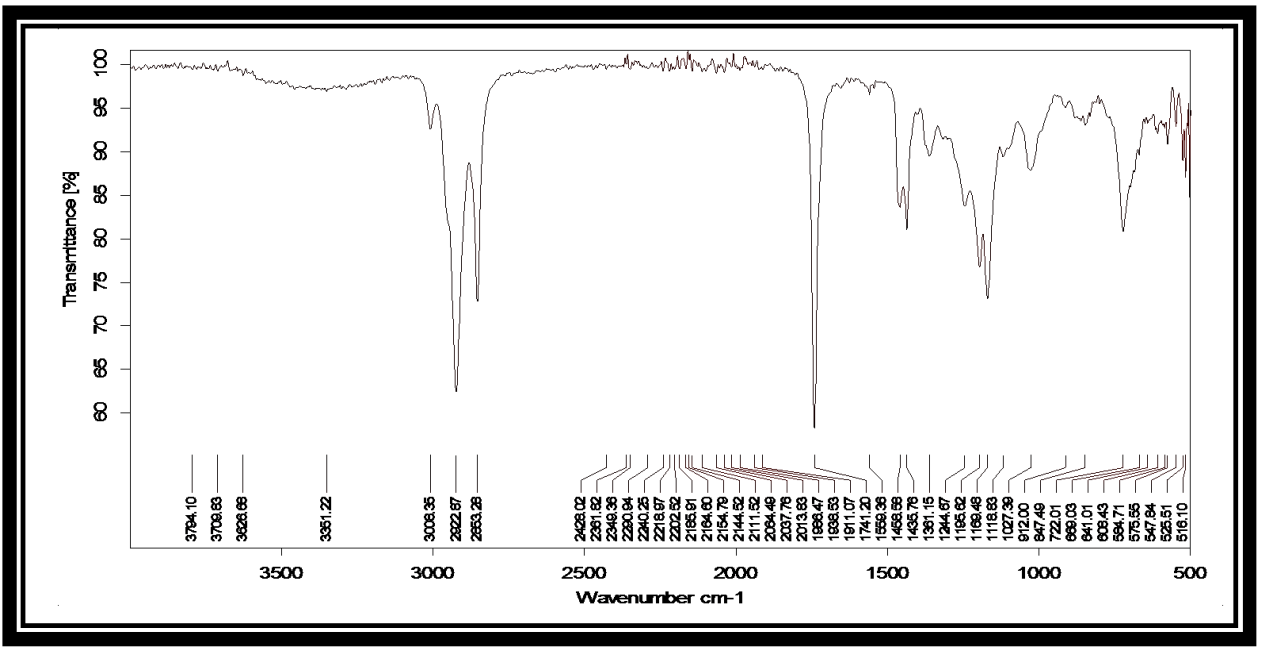

Figure 2. FTIR of BLF.

Table 2. FTIR results for diesel and BLF.

\begin{tabular}{llllll}
\hline \multicolumn{2}{l}{ Diesel } & \multicolumn{3}{c}{ BLF } \\
\hline Frequency Range $\left.\mathbf{( c m}^{-\mathbf{1}}\right)$ & Bond Types & Family & Frequency Range $\left.\mathbf{( c m}^{-\mathbf{1}}\right)$ & Bond Types & Family \\
\hline $2922.03-2852.59$ & C-H stretch & Alkanes & $2922.87-2853.26$ & C-H stretch & Alkanes \\
1459.09 & C-H bend & Alkanes & 1458.58 & C-H bend & Alkanes \\
1377.09 & C-X & Flouride & 1361.15 & C-X & Fluoride \\
722.01 & C-H bend & Alkanes & 722.02 & C-H bend & Alkanes \\
\hline
\end{tabular}




\subsection{Engine Setup}

A $5.5 \mathrm{~kW}$ single-cylinder water-cooled direct-injection diesel engine has been examined in this study. The details of the engine specifications are given in Table 3. The engine was coupled to a hydraulic dynamometer for the measurement of the torque. A laser sensor was used to measure the engine speed. A calibrated load cell was attached with the dynamometer. An electronic weighing scale was used to measure the fuel flow rate. The emission and performance parameters were measured as per ISO-3046 standard [28]. Exhaust gas temperature was directly measured by using thermocouples installed at the inlet and outlet pipes. The schematic diagram of the experimental setup is shown in Figure 3.

Table 3. Technical specifications of the engine used in the present study.

\begin{tabular}{|c|c|c|}
\hline & Particulars & Details \\
\hline \multirow{10}{*}{ Engine } & Model & Kirolaskar TAF-1 \\
\hline & Maximum power $(\mathrm{kW})$ & 5.5 \\
\hline & Type & Water-cooled, four stroke \\
\hline & Rated speed (rpm) & 1600 \\
\hline & Number of cylinders & 1 \\
\hline & Bore & $87.5 \mathrm{~mm}$ \\
\hline & Stroke & $110 \mathrm{~mm}$ \\
\hline & Compression ratio & 17.5:1 \\
\hline & Combustion & Direct injection (DI) and naturally aspirated \\
\hline & Injection timing & $23^{\circ}$ before TDC \\
\hline \multirow{13}{*}{ Gas analyzer } & Model & AVL Di Gas 444 \\
\hline & $\mathrm{HC}(\mathrm{ppm})$ & - \\
\hline & Accuracy & $\pm 4 \%$ \\
\hline & Range & 0 to 30,000 \\
\hline & Resolution & 1 \\
\hline & $\mathrm{CO}(\%)$ & - \\
\hline & Accuracy & \pm 0.06 \\
\hline & Range & 0 to 15 \\
\hline & Data resolution & 0.001 \\
\hline & $\mathrm{NO}_{x}(\mathrm{ppm})$ & - \\
\hline & Range & 0 to 5000 \\
\hline & Accuracy & $\pm 2 \%$ \\
\hline & Resolution & 1 \\
\hline \multirow{5}{*}{ Smoke meter } & - & AVL 437 \\
\hline & Accuracy & $\pm 1 \%$ \\
\hline & Range & $0-100 \%$ \\
\hline & Alarming signal temperataure & $70^{\circ} \mathrm{C}$ \\
\hline & Light Source & Halogen Lamp, $12 \mathrm{~V}$ \\
\hline
\end{tabular}

An AVL-437 smoke meter (AVL, Graz, Austria) was used to measure smoke opacity. For the measurement of carbon monoxide (CO), hydrocarbons (HC), and nitrous oxide $\left(\mathrm{NO}_{x}\right)$, an AVL 444 DI gas analyzer (AVL, Graz, Austria) was used. Before every measurement was taken, the engine was started and warmed up to attain steady speed. The temperature was maintained by circulating water. The performance and emission variables were measured at an engine speed of $1500 \mathrm{rpm}$ with different engine loads. The output signal was collected by a data acquisition board and sent to a personal computer. The tests were repeated and mean value of three measurements was used for the calculations. 


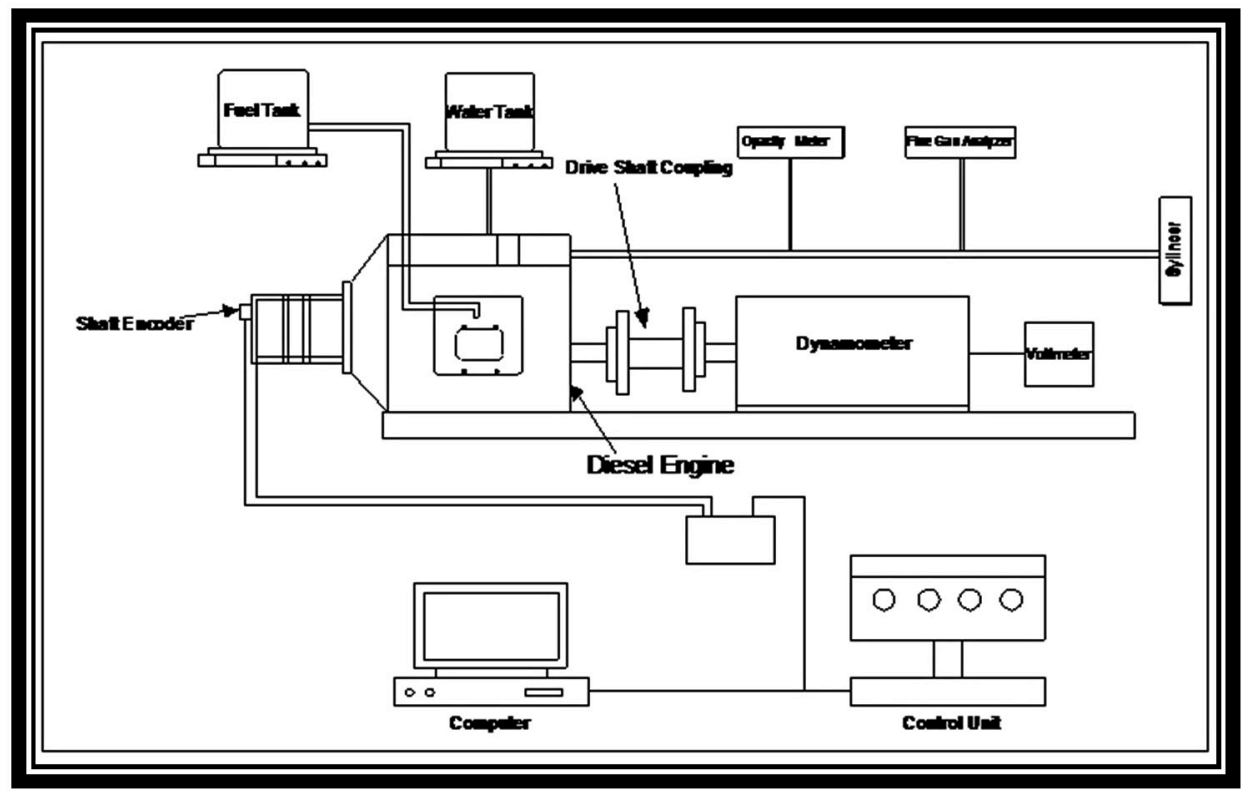

Figure 3. Sharper Image of the experimental setup.

A piezoelectric sensor (6258c, Kistler, Switzerland) was used to measure the combustion pressure. Using the diagram of the pressure crank angle, the ignition delay (the time difference between the start of injection and the start of combustion) was calculated with help of following relationship:

$$
\text { Ignition delay }=3.45 \times 10^{(2100 / \mathrm{Tm}) \mathrm{Pm}-1.02}
$$

Here, $\mathrm{Tm}$ is the mean temperature and $\mathrm{Pm}$ is the mean pressure during ignition delay.

The heat release rate (HRR) of BLF blends and diesel combustion was calculated using Equation (2) below [29]:

$$
\Delta \mathrm{Q} / \Delta \theta=(\mathrm{K} / \mathrm{K}-1 \times \mathrm{P} \times \Delta \mathrm{V} / \Delta \theta)+(1 / \mathrm{K}-1 \times \mathrm{V} \times \Delta \mathrm{P} / \Delta \theta)
$$

where $\Delta \mathrm{Q} / \Delta \theta$ is the HRR, $k$ is the specific heat ratio (1.35), $\Delta \mathrm{V} / \Delta \theta$ is the rate of change of the cylinder volume, and $\Delta \mathrm{P} / \Delta \theta$ is the rate of change of the pressure.

\section{Results and Discussions}

\subsection{Fuel Properties}

Table 4 describes the various fuel properties of biodiesel like fuel blends (BLF15, BLF20, BLF25, and BLF100) and petroleum diesel. The fuel properties were analyzed by following international standards (ASTM methods). It can be noted from the Table 4 that all the measured fuel properties of BLF blends are comparable to those of diesel fuel and all of the measured results were found within EN 4214, ASTM D6751, and BIS 15607 international standard allowable limits of biodiesel fuel.

\begin{tabular}{|c|c|c|c|c|c|c|c|c|c|c|}
\hline Properties & Units & $\begin{array}{c}\text { Method } \\
\text { ASTM }\end{array}$ & Diesel & BLF100 & BLF15 & BLF20 & BLF25 & $\begin{array}{c}\text { ASTM } \\
6751\end{array}$ & $\begin{array}{c}\text { EN } \\
14214\end{array}$ & $\begin{array}{c}\text { BIS } \\
15607\end{array}$ \\
\hline Density at $15^{\circ} \mathrm{C}$ & $\left(\mathrm{Kg} / \mathrm{m}^{3}\right)$ & D-1298 & 834 & 886 & 836 & 841 & 845 & - & $860-900$ & $860-900$ \\
\hline Kin.Viscosity at $40^{\circ} \mathrm{C}$ & cSt & D-445 & 2.96 & 5.56 & 3.18 & 3.24 & 3.31 & $1.9-6.0$ & $3.5-5.0$ & $2.5-6.0$ \\
\hline Flash Point & ${ }^{\circ} \mathrm{C}$ & D-93 & 60 & 166 & 71 & 83 & 88 & $>130$ & $>120$ & $>120$ \\
\hline Pour Point & ${ }^{\circ} \mathrm{C}$ & D-97 & -12 & 6 & -9 & -6 & -3 & - & - & - \\
\hline Cetane Number & - & D-976 & 53 & 54 & 54.5 & 55 & 55.5 & - & - & - \\
\hline
\end{tabular}

Table 4. Fuel properties of diesel, BLF, and its blends. 


\subsection{Combustion and Engine Performance}

\subsubsection{Ignition Delay}

Figure 4 shows the ignition delay of BLF fuel blends and that of diesel. Ignition delay is measured in the degree of the crank angle that helps to determine the heat release and maximum pressure rate [30]. The ignition delay of BLF fuel blends was decreased with the increase in the engine load. This trend is authentic, because as the engine load increases the heat inside the cylinder increases, which supports the fuel mixture to ignite earlier. In comparison to diesel, shorter ignition delay was observed in BLF fuel blends. The ignition delay for diesel was $10.6{ }^{\circ} \mathrm{CA}$ and for BLF15, BLF-20 and BLF25, it was $10.40,10.11$, and $9.51{ }^{\circ} \mathrm{CA}$ respectively. The reason for the shorter ignition delay may be the higher cetane number of BLF blends and the higher oxygen content in biodiesel contents of the BLF fuel mixture. This is agreed by Chuah et al. [31] who reported that a higher cetane number and higher oxygen content of biodiesel than diesel exhibits a shorter ignition delay time and allows for better combustion of the fuel.

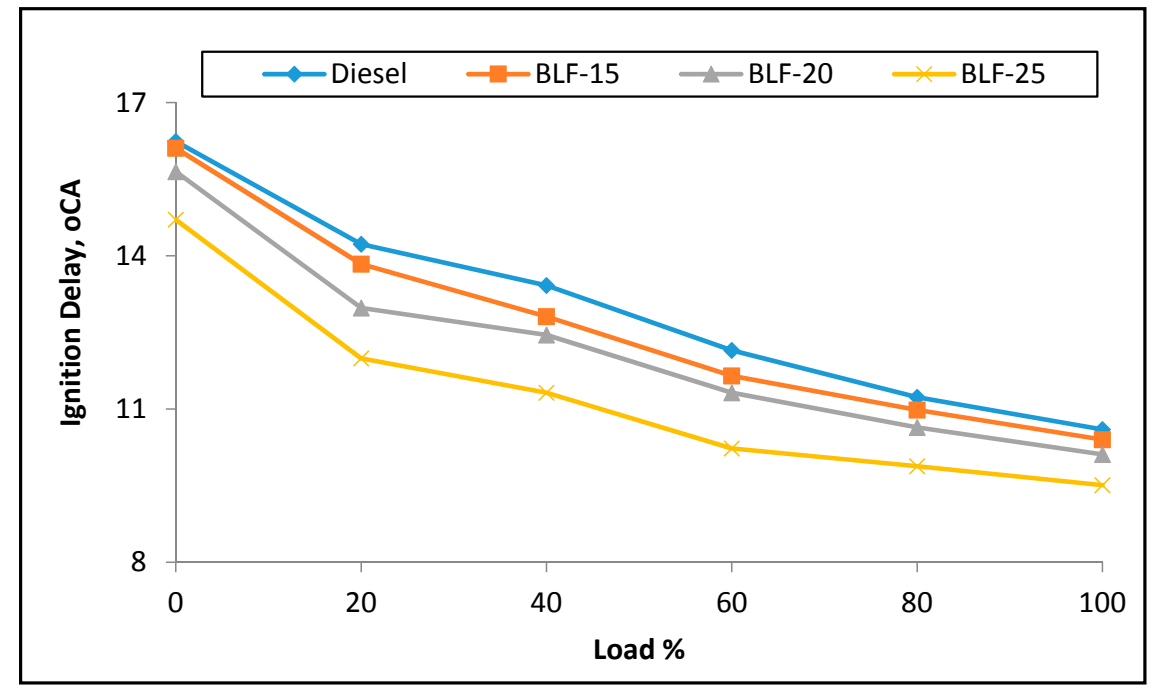

Figure 4. Variations of ignition delay vs. engine load percent.

\subsubsection{Heat Release Rate}

Figure 5 shows HRR (heat release rate) corresponding to every crank angle for BLF fuel blends and diesel at maximum engine load conditions. It is reported in the previous studies that, in the premixed combustion phase, the HRR depends on the ignition delay, combustion rate, and mixture formation in the initial combustion stages [30]. It is also reported that the second peak may or may not be reached in the diffusion combustion phase. From Figure 5, it can be observed that in the diffusion combustion phase, the second peak does not appear. The maximum HRR for diesel, BLF15, BLF20, and BLF25 was observed at 364.34, 365.23, 365.67, and $365.84^{\circ} \mathrm{CA}$, respectively. Higher HRR values were found in BLF blends as compared to diesel due to sufficient oxygen contents in the biodiesel portion of BLF which catalyzes combustion activation. 


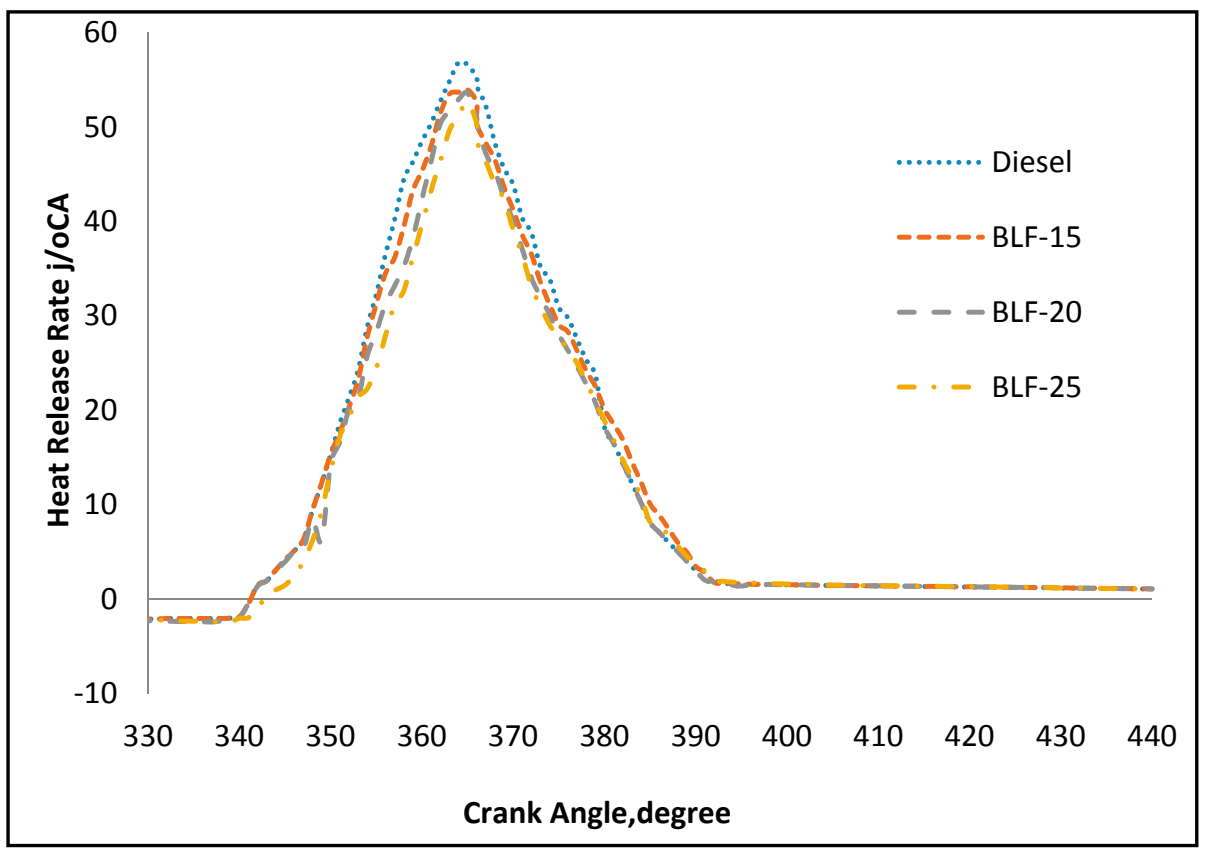

Figure 5. Variations of heat release rate vs. crank angle, in degrees at maximum engine load.

\subsubsection{Maximum Cylinder Pressure}

Variations of maximum cylinder pressure with engine load percent for the BLF blends and diesel are shown in Figure 6. The maximum cylinder pressure for diesel was observed at 76.5 bar, and for BLF15, BLF20, and BLF25 it was 77.2, 78.6 and 79.8 bar, respectively, at maximum engine load conditions. Increased cylinder pressure of BLF blends in comparison to that of diesel is due to a higher heat release in the premixed combustion phase because of oxygen-catalyzed combustion activation. The cylinder pressure in a diesel engine depends mostly on the combustion rate in the initial stages of premixed combustion and the amount of fuel accumulated in the delay period [30].

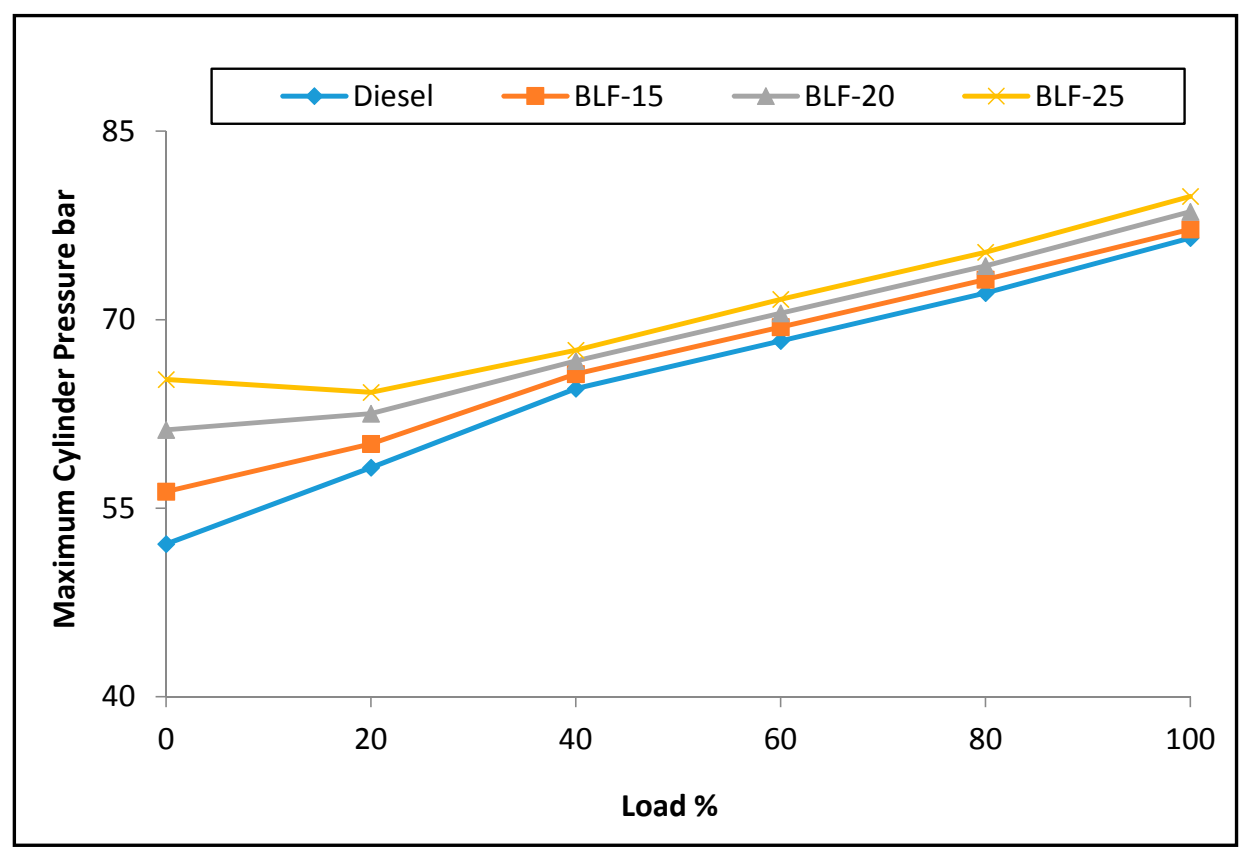

Figure 6. Variations of maximum cylinder pressure vs. engine load percent. 


\subsubsection{Brake Specific Fuel Consumption (BSFC)}

Figure 7 demonstrates the variations of the brake specific fuel consumption with engine load for petroleum diesel and the blends BLF15, BLF20, and BLF25. It was observed that BSFC was found to increase with an increase of BLF concentrations in the fuel blends. BSFC values of diesel, BLF15, BLF20, and BLF25 were measured as $613.21,632.02,645.14$, and $655.23 \mathrm{~g} / \mathrm{kW} \cdot \mathrm{h}$, respectively, at $20 \%$ load condition, which decreased to $277.32,284.21,290.48$, and $295.23 \mathrm{~g} / \mathrm{kW} \cdot \mathrm{h}$, respectively, at $100 \%$ engine load.BLF15 has shown a minimum fuel consumption value as compared to BLF20 and BLF25 fuel blends. BSFC of BLF15, BLF20, and BLF25 was found to increase $2.48 \%, 4.74 \%$, and $6.54 \%$ as compared to that of diesel fuel due to lower heating values of BLF blends as compared to diesel. BSFC was found to decrease with an increase of engine load conditions. This is attributed to the fact that the engine faces fewer amounts of heat losses at higher loads [31].

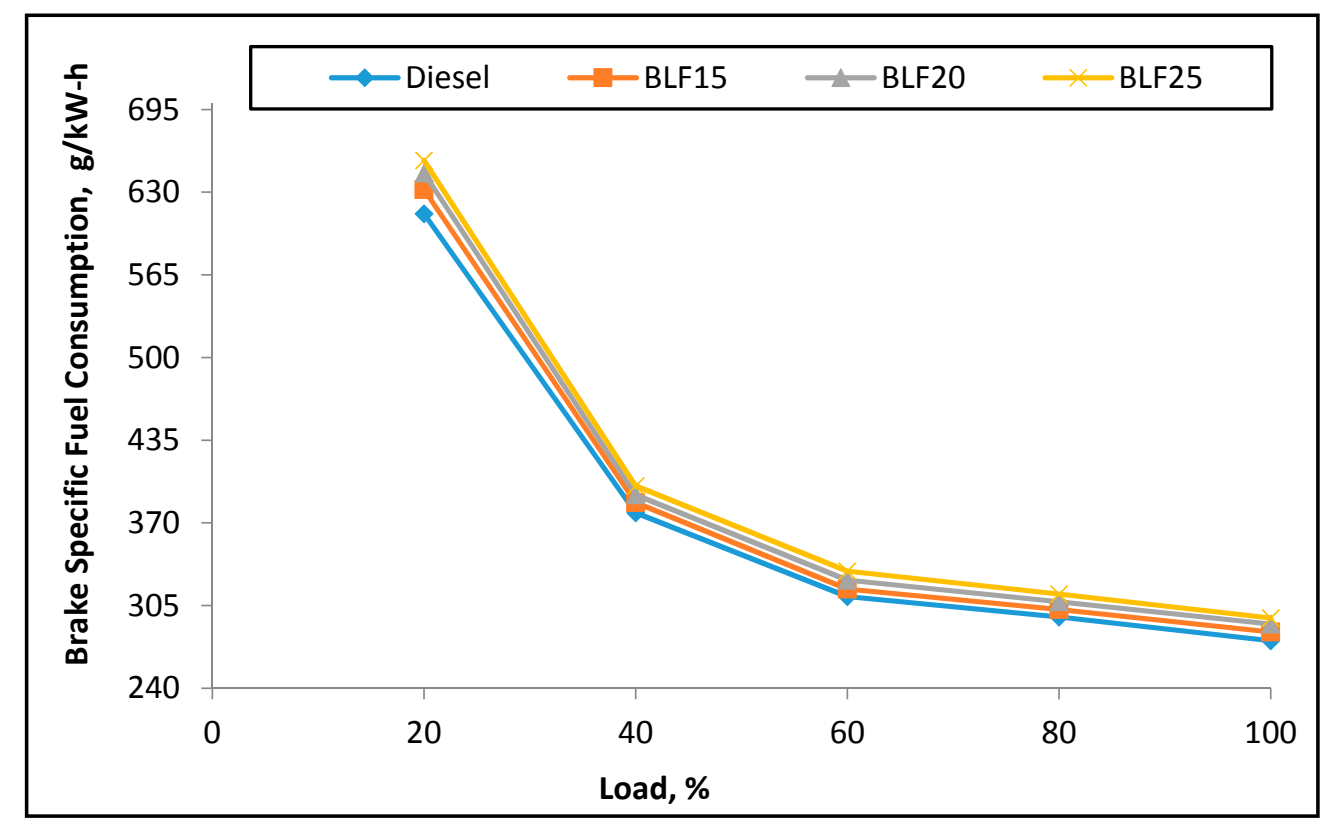

Figure 7. Variations of BSFC vs. load percent.

\subsubsection{Brake Thermal Efficiency (BTE)}

BTE of diesel engine with diesel, BLF15, BLF20, and BBLF25 at various engine loads is shown in Figure 8 . The observed values were $30.52 \%, 29.91 \%, 29.45 \%$, and $29.02 \%$ with diesel, BLF15, BLF20, and BLF25 at maximum load. The BTE value of BLF15 was found very close to that of diesel fuel. BTE was found to increase with increase in engine load and BTE values of all BLF fuel blends were found to be $1.99 \%$ to $4.91 \%$ less than diesel due to lower calorific values of BLF blends in comparison to diesel, as shown in Table 4. The decrease in BTE is also because of increased brake power and reduced heat losses of the engine at higher loads [32]. 


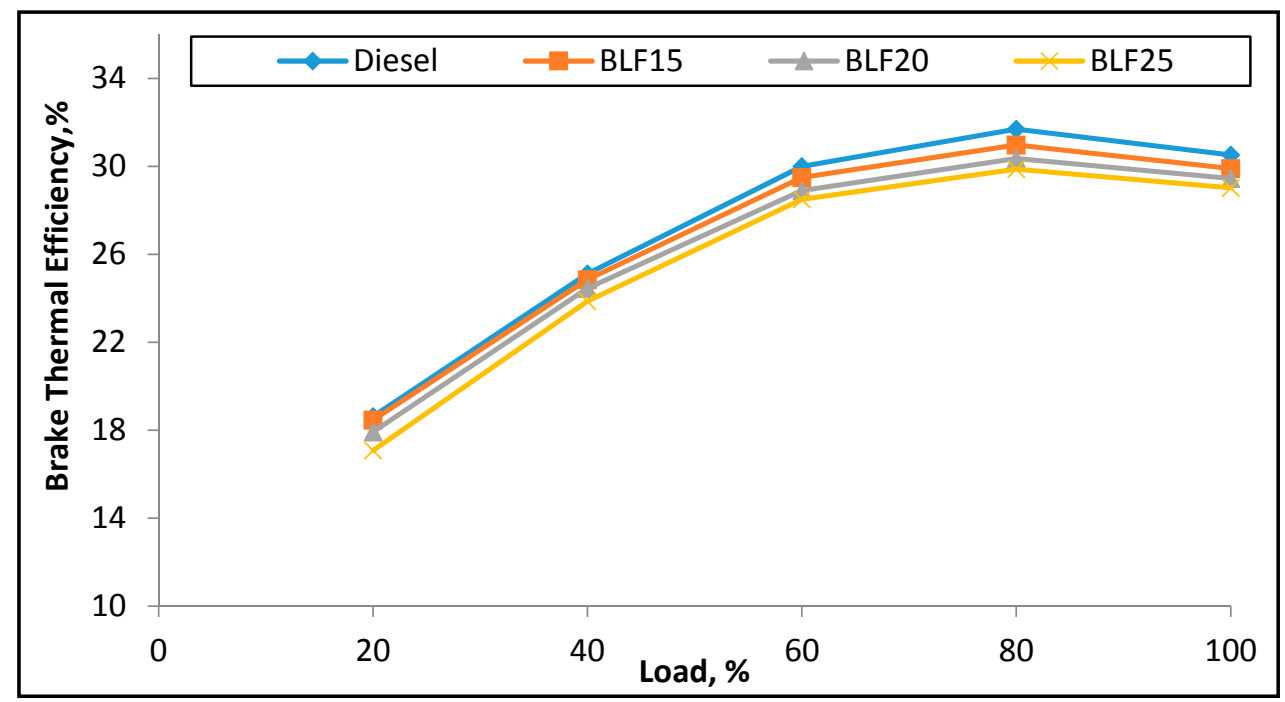

Figure 8. Variations of BTE vs. load percent.

\subsubsection{Exhaust Gas Temperature (EGT)}

Figure 9 shows the EGT of a diesel engine when fuelled with diesel, BLF15, BLF20, and BLF25 at various engine loads. The EGT values for diesel, BLF15, BLF20, BLF25, were found to be $217^{\circ} \mathrm{C}$, $224{ }^{\circ} \mathrm{C}, 228^{\circ} \mathrm{C}$, and $232{ }^{\circ} \mathrm{C}$, respectively, at $20 \%$ load of the engine, which increased to $416^{\circ} \mathrm{C}, 423^{\circ} \mathrm{C}$, $429^{\circ} \mathrm{C}$, and $434^{\circ} \mathrm{C}$, respectively, at maximum engine load. The EGT values of BLF15, BLF20, and BLF25 were seen to be $1.68 \%, 3.12 \%$, and $4.33 \%$ higher than that of diesel at $100 \%$ load.

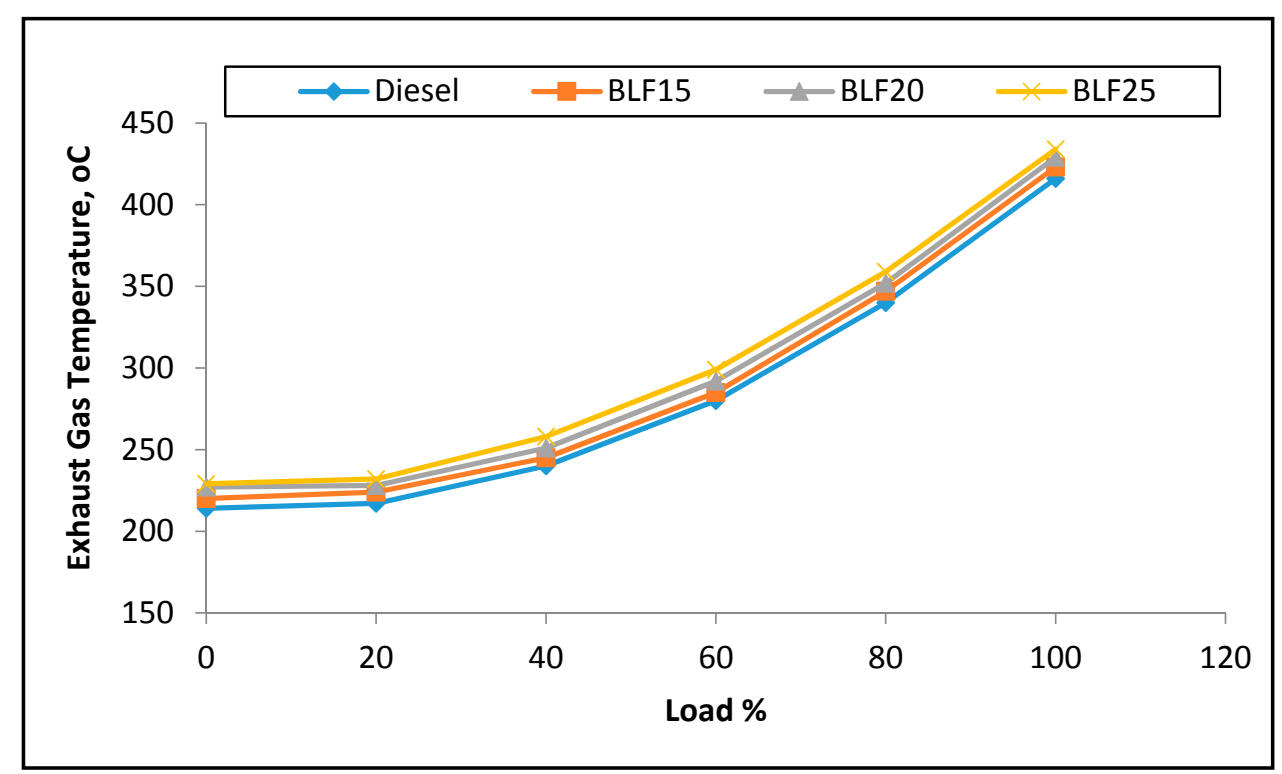

Figure 9. Variations of EGT vs. engine load percent.

The EGT value of BLF15 was seen to be closer to that of petroleum diesel at full load conditions. The increase in EGT with heavier loads is due to the fact that the engine takes up the additional loads by applying more power [29]. All of the results are technically in line with the previous studies [33-39]. 


\subsection{Engine Emissions}

\subsubsection{Carbon Monoxide (CO)}

Behavior of the engine with respect to CO emissions when operated with diesel, BLF15, BLF20, and BLF25 at different engine loads is given in Figure 10. CO emission was observed to decrease with the increase in BLF proportions in the fuel mixture. The observed value for CO emission with HSD, BLF15, BLF20, and BLF25 was $0.033 \%, 0.029 \%, 0.028 \%$, and $0.027 \%$, respectively, at $20 \%$ load, which was decreased to $0.022 \%, 0.015 \%, 0.016$, and $0.018 \%$, respectively, at $60 \%$ load. At maximum load the CO emissions of BLF15, BLF20, and BLF25 were $3.80 \%, 5.06 \%$, and $6.32 \%$ lower as compared to that of diesel fuel. The CO emission of BLF15 was found closer to that of diesel, but higher than those of BLF20 and BLF25 fuel blends. The average value of CO emissions of BLF15 was $0.043 \%$ at no load condition, which was decreased to $0.022 \%$ at $60 \%$ load, which then elevated to $0.086 \%$ at the maximum load of the engine. A similar trend was found for BLF20, BLF25, and diesel fuel. The cylinder temperature may be too low at no load conditions then with an increase in loading, it increased due to greater fuel injection inside the cylinder [34].

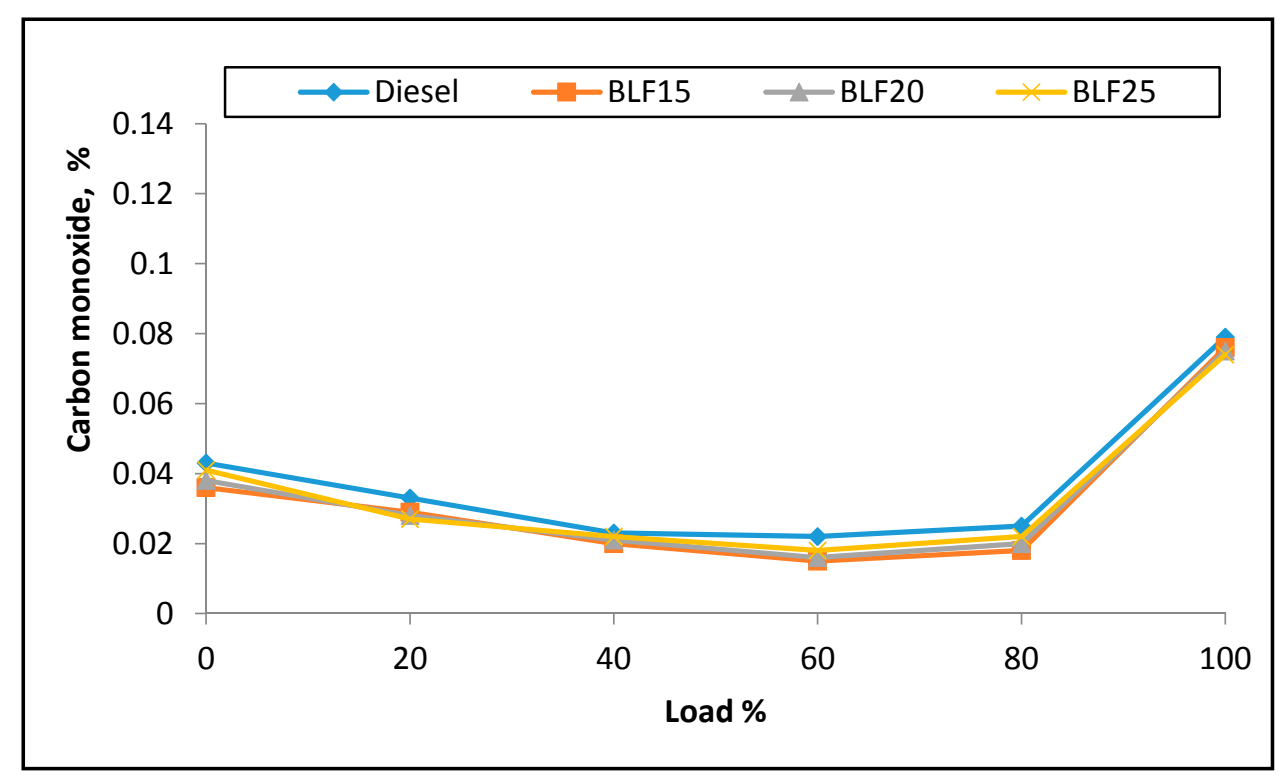

Figure 10. Variations of $\mathrm{CO}$ vs. load percent.

\subsubsection{Hydrocarbons (HC)}

In Figure 11, the engine shows HC emissions with the fuels BLF15, BLF20, BLF25, and diesel. With all the fuels tested, the values of $\mathrm{HC}$ emissions were continuously lowered from $0 \%$ to $60 \%$ engine load, and then increased along with the increase of the engine load to $100 \%$. A similar trend was seen as observed for $\mathrm{CO}$ emissions.

The values of HC emissions with BLF15, BLF20, and BLF25 were observed to be $10.92 \%, 22.06 \%$, and $31.17 \%$ less than petroleum diesel, respectively. Higher contents of oxygen in biodiesel fuel enhance the rate of combustion, hence, unburnt HC emissions are decreased. This is in accordance with many other reported studies [40,41]. Among all the blends analyzed, the BLF15 blend shows minimum reductions of $\mathrm{HC}$ emissions as compared with petroleum diesel. 


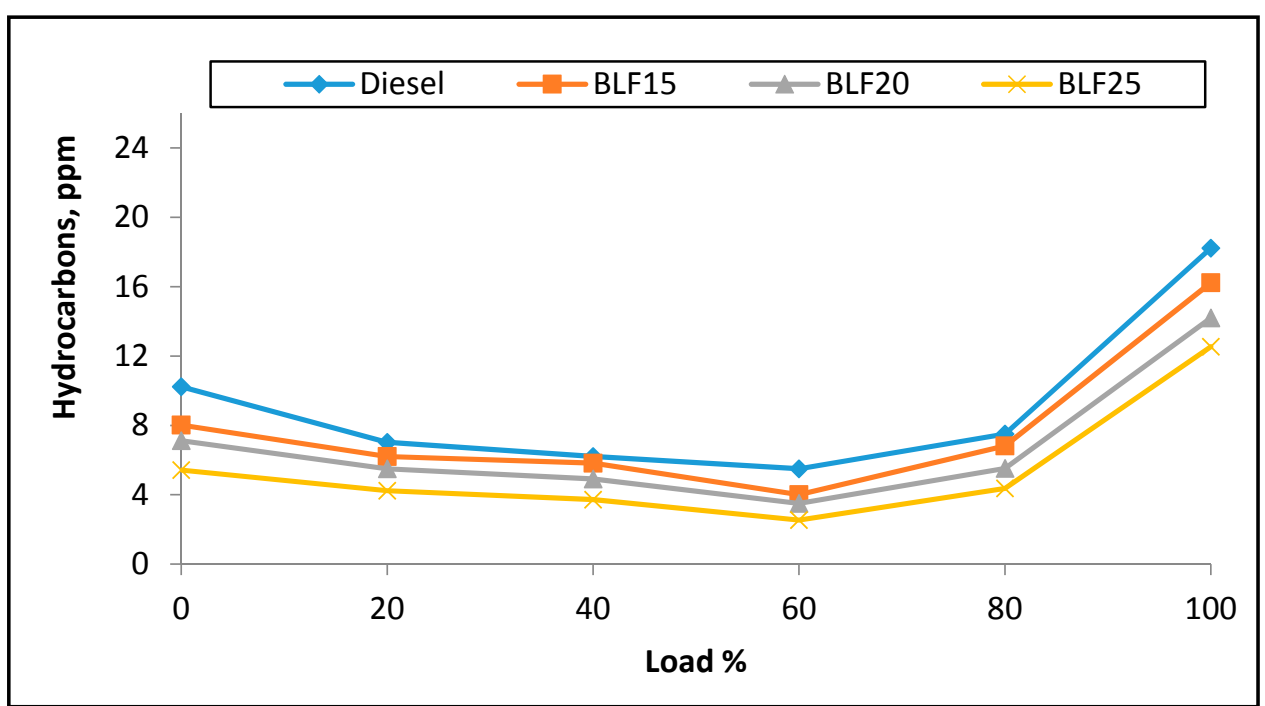

Figure 11. Variations of $\mathrm{HC}$ vs. engine load percent.

\subsubsection{Oxides of Nitrogen $\left(\mathrm{NO}_{x}\right)$}

$\mathrm{NO}_{x}$ concentrations in the exhaust gas emissions of the engine operated with BLF15, BLF20, BLF25, and diesel were 305 ppm, 341 ppm, 372 ppm, and 275 ppm, correspondingly at 20\% load of the engine, which then increased to 1273 ppm, $1297 \mathrm{ppm}, 1330 \mathrm{ppm}$, and $1234 \mathrm{ppm}$, respectively, at full load conditions, as shown in Figure 12. The $\mathrm{NO}_{x}$ values observed for BLF15, BLF20, and BLF25 were $3.16 \%, 5.1 \%$, and $7.78 \%$ higher than petroleum diesel, correspondingly. The higher values of $\mathrm{NO}_{x}$ are due to the higher oxygen contents in biodiesel fuel blends [34].

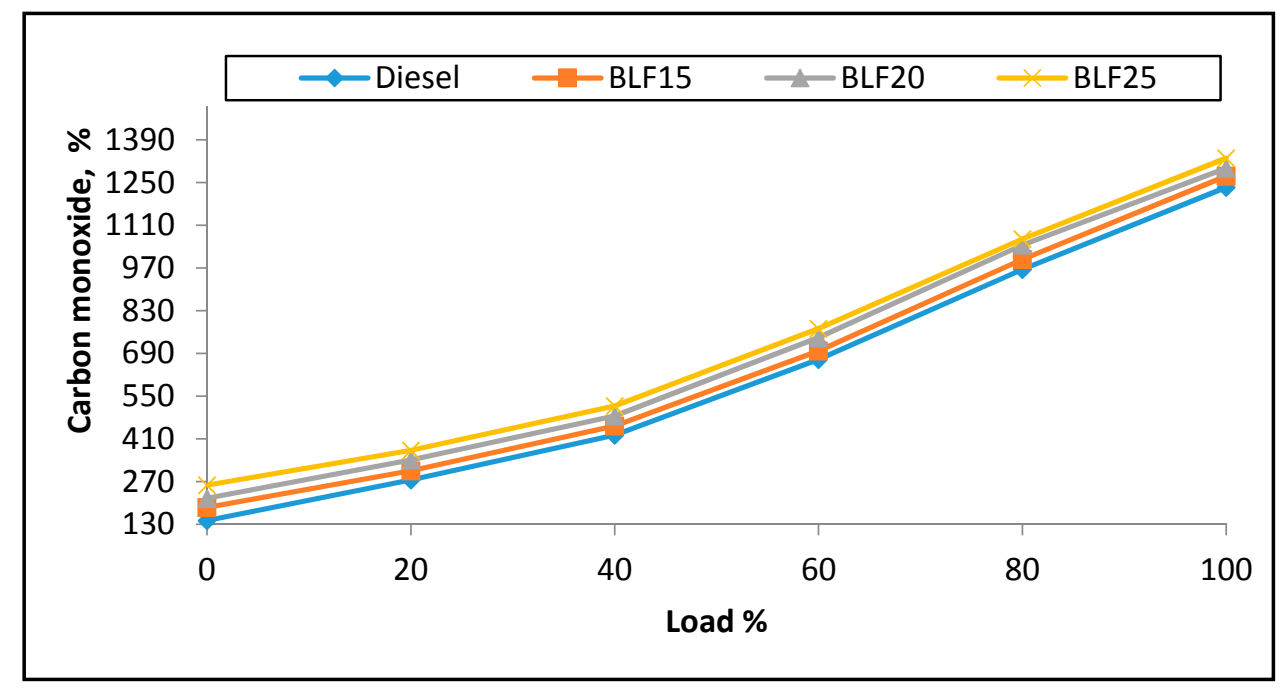

Figure 12. Variations of $\mathrm{NO}_{x}$ vs. load percent.

\subsubsection{Smoke Opacity}

Figure 13 shows the changes in smoke opacity that indicates the soot content present in the exhaust gases. The smoke opacity for fuel blends BLF15, BLF20, BLF25, and diesel was observed to be $6.52 \%, 5.50 \%, 5.12 \%$, and $5.99 \%$, respectively, at no load conditions, however, the values were $10.52 \%$, $9.12 \%, 8.90 \%$, and $11.42 \%$, respectively, at $20 \%$ load, which increased to $32.90 \%, 32.51 \%, 31.62 \%$, and $33.36 \%$, respectively, at maximum load conditions. 


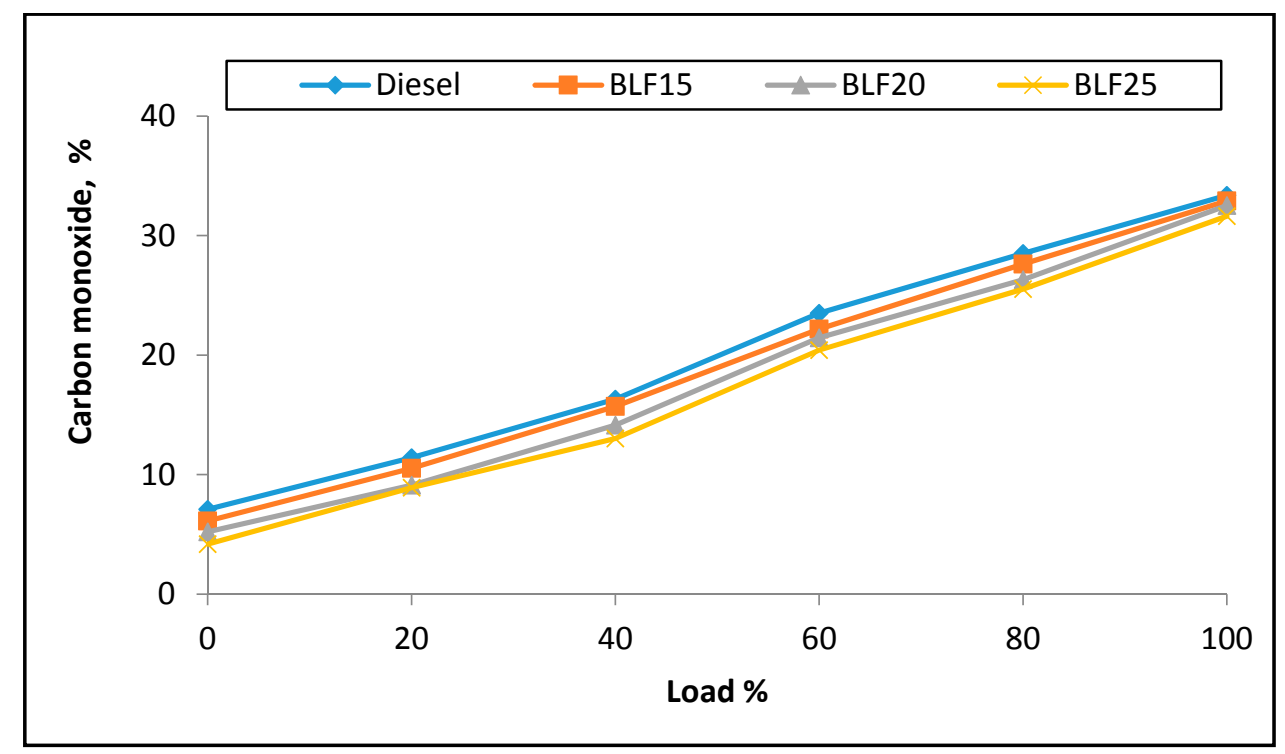

Figure 13. Variations of smoke vs. load percent.

It was noted that the smoke opacity was decreased with the increase in the BLF concentrations in the fuel mixtures, while it was increased with increasing engine load percentage. All BLF fuel blends have shown lower smoke values as compared to diesel fuel. The decrease in smoke values with the increase in the BLF blend concentrations is attributed to the higher oxygen contents in the biodiesel fuels [38,42]. It is experimentally observed that high smoke opacity of petroleum diesel is due to the higher concentration of sulfur content [39] and a higher carbon to hydrogen ratio as compared to biofuels. The absence of aromatic compounds, higher oxygen content, and lower carbon content decreases the tendency of fuel for soot production [43].

\section{Conclusions}

Global warming due to fossil fuel emissions, depletion of petroleum product reserves, population growth, and crude oil price hikes has stimulated researchers to search out environmentally-friendly alternative energy resources. The aim of this work was to study the combustion, performance, and emission characteristics of a $5.5 \mathrm{~kW}$ four-stroke single-cylinder water-cooled direct-injection diesel engine operated with blends of biodiesel-like fuel (BLF15, BLF20, and BLF25) obtained from a 50:50 mixture of transesterified waste transformer oil (TWTO) and waste canola oil methyl esters (WCOME) with petroleum diesel. The mixture of the waste oils was named as biodiesel-like fuel (BLF). The following conclusions were made on the basis of the present research work:

- The results of FTIR analysis have confirmed that BLF fuel has similar characteristics to that of petroleum diesel showing saturated alkane structures.

- It is observed that fuelobtained from the mixture of transesterified waste transformer oil (TWTO) and waste canola oil methyl esters (WCOME) have fuel properties comparable to petroleum diesel and were found within the international specified standard (EN 14214, BIS 15607 and ASTM 6751-03) limits of biodiesel fuel.

- In comparison to diesel, a shorter ignition delay was observed BLF fuel blends. This was a good indication for better combustion of the proposed fuel blends.

- EGT and BSFC of BLF fuel blends were found to increase $1.68-4.33 \%$ and $2.48-6.45 \%$, respectively, as compared to petroleum diesel at maximum load conditions, however, BTE decreased $1.99-4.91 \%$ with the increase in BLF concentrations in the fuel blend. BLF15 has a lower fuel consumption value $(632.02 \mathrm{~g} / \mathrm{kW} \cdot \mathrm{h})$, higher BTE $(29.91 \%)$, and lower EGT (224 ${ }^{\circ} \mathrm{C}$ at minimum engine load) as compared to BLF20 and BLF25 fuel blends. 
- $\quad \mathrm{HC}$ and CO emissions of the diesel engine with BLF fuel blends were observed to reduce by $10.92-31.17 \%$ and $3.80-6.32 \%$, respectively, as compared to those of diesel fuel. The smoke density was reduced by $1.39-5.21 \%$, whereas $\mathrm{NO}_{x}$ emissions were found to increase by $3.16-7.78 \%$ in relation to diesel fuel.

- Minimum decrease of $\mathrm{CO}, \mathrm{HC}$, smoke value, and minimum increase of $\mathrm{NO}_{x}$ emissions were found with BLF15. BSFC, EGT, and BTE values of the BLF15 fuel blend are closer to those of petroleum diesel. It is, therefore, suggested that this fuel blend may be used in diesel engines without any engine modifications.

- Pakistani waste transformer and waste canola oils have been successfully converted into fuel which might boost the country's economy by saving its crude oil import bills. Additionally, the outcome of this research work is to minimize the environmental problems arising from the waste oil disposals.

Acknowledgments: The work presented in this paper was part of the work of Muhammad Qasim. The research work was supported by the Institute of Chemical Sciences, Bahauddin Zakariya University, Multan, and M/s Chicago Metal Works Pvt. Ltd. Multan. Publication fees were provided by the authors voluntarily.

Author Contributions: This work was written and developed by Muhammad Qasim. The work supervisors Tariq Mahmood Ansari and Mazhar Hussain provided major editorial contributions and guidance.

Conflicts of Interest: The authors declare no conflict of interest.

\section{References}

1. Agarwal, A.K. Biofuels (alcohols and biodiesels) application as fuels for internal combustion engines. Prog. Energy Combust. Sci. 2007, 33, 233-271. [CrossRef]

2. Demirbas, A. Progress and recent trends in biofuels. Prog. Energy Combust. Sci. 2007, 33, 1-18. [CrossRef]

3. Graboski, M.S.; McCormick, R.L. Combustion of fat and vegetable oil derived fuels in diesel engines. Prog. Energy Combust. Sci. 1998, 24, 125-164. [CrossRef]

4. McCormick, R.L.; Tennant, C.J.; Hayes, R.R.; Black, S.; Ireland, J.; McDaniel, T.; Williams, A.; Frailey, M.; Sharp, C.A. Regulated emissions from biodiesel tested in heavy duty engines meeting 2004 emission standards. In Proceedings of the 2005 SAE Brasil Fuels \& Lubricants Meeting, Rio De Janeiro, Brazil, 11-13 May 2005.

5. Yoon, S.H.; Park, S.H.; Lee, C.S. Experimental investigation on the fuel properties of biodiesel and its blends at various temperatures. Energy Fuels 2008, 22, 652-656. [CrossRef]

6. Yoon, S.H.; Lee, C.S. Experimental investigation on the combustion and exhaust emission characteristics of biogas-biodiesel dual-fuel combustion in a CI engine. Fuel Process. Technol. 2011, 92, 992-1000. [CrossRef]

7. Yoon, S.H.; Cha, P.J.; Lee, C.S. An investigation of the effects of spray angle and injection strategy on dimethyl ether (DME) combustion and exhaust emission characteristics in a common-rail diesel engine. Fuel Process. Technol. 2010, 91, 1364-1372. [CrossRef]

8. Li, L.; Wang, J.; Wang, Z.; Xiao, J.H. Combustion and emission characteristics of diesel engine fueled with diesel/biodiesel/pentanol fuel blends. Fuel 2015, 15, 211-218. [CrossRef]

9. Kalantar, A.; Levin, M. Factors affecting the dissolution of copper in transformer oils. Lubr. Sci. 2008, 20, 223-240. [CrossRef]

10. Hara, I. Health status and PCBs in blood of workers exposed to PCBs and of their children. Environ. Health Perspect. 1985, 59, 85-90. [CrossRef] [PubMed]

11. Gustavsson, P.; Hogstedt, C. A cohort study of swedish capacitor manufacturing workers exposed to polychlorinated biphenyls (PCBs). Am. J. Ind. Med. 1997, 32, 234-239. [CrossRef]

12. Lobeiras, A.; Sabau, J. Particle counting of insoluble decay products in mineral insulating oils. In Proceedings of the 2000 Symposium of the American Society for Testing and Materials (ASTM), Toronto, ON, Canada, 2000.

13. Sierota, A.; Rungis, J. Electrical insulating oils. Part-1: Characterization and pre-treatment of new transformer oils. IEEE Electr. Insul. Mag. 1995, 11, 8-20. [CrossRef]

14. Pullagura, G.; Kumar, K.R.; Verma, P.C.; Jaiswal, A. Experimental investigation of hydrogen enrichment on performance and emission behavior of CI engine. Int. J. Eng. Sci. Technol. 2012, 4, 1223-1232. 
15. Kurki, A.; Hill, A.; Morris, M. Biodiesel: The Sustainability Dimensions; ATTRA Publication: Butte, MT, USA, 2006; pp. 1-12. Available online: http:/ / attra.ncat.org/attra-pub/PDF/biodiesel_sustainable.pdf (accessed on 1 January 2017).

16. Khan, M.I.; Chhetri, A.B.; Islam, M.R. Analyzing Sustainability of Community Based Energy Technologies. Energy Sources 2007, 2, 403-419. [CrossRef]

17. Abdullah, N.H.; Hassan, S.H.; Yusoff, N.R.M. Biodiesel production based on waste cooking oil (WCO). Int. J. Mater. Sci. Eng. 2013, 1, 94-99. [CrossRef]

18. Kaanagbara, L.; Inyang, H.I.; Wu, J.; Hilger, H. Aromatic and aliphatichydrocarbon balance in electric transformer oils. Fuel 2010, 89, 3114-3118. [CrossRef]

19. Murugan, S.; Ramaswamy, M.C.; Nagarajan, G. The use of tyre pyrolysis oil in diesel engines. J. Waste Manag. 2008, 28, 2743-2749. [CrossRef] [PubMed]

20. Lee, W.J.; Liu, Y.-C.; Mwangi, F.K.; Chen, W.-H.; Lin, S.-L.; Fukushima, Y.; Liao, C.-N.; Wang, L.-C. Assessment of energy performance and airpollutant emissions in a diesel engine generator fueled withwater-containing ethanol-biodiesel-diesel blend of fuels. Energy 2011, 36, 5591-5599. [CrossRef]

21. Mani, M.; Subash, C.; Nagarajan, G. Performance, emission and combustioncharacteristics of a CI diesel engine using waste plastic oil. Appl. Therm. Eng. 2009, 29, 2738-2744. [CrossRef]

22. Arpa, O.; Yumrutaş, R.; Argunhan, Z. Experimental investigation of the effects ofdiesel-like fuel obtained from waste lubrication oil on engineperformance and exhaust emission. Fuel Process. Technol. 2010, 91, 1241-1249. [CrossRef]

23. Rakopoulos, C.; Hountalas, D.T.; Giakoumis, E.G.; Andritsakis, E.C. Performance and emissions of bus engineusing blends of diesel fuel with bio-diesel of sunflower orcottonseed oils derived from Greek feedstock. Fuel 2008, 87, 147-157. [CrossRef]

24. Recep, Y.; Mehmet, H.A.; Hakan, Ö.; Önder, K. Investigation of purified sulphates turpentine on engine performance and exhaust emission. Fuel 2008, 87, 252-259.

25. Arpa, O.; Yumrutaş, R.; Kaşka, Ö. Desulfurization of diesel-like fuel produced fromwaste lubrication oil and its utilization on engine performanceand exhaust emission. Appl. Therm. Eng. 2013, 58, 374-381. [CrossRef]

26. Behera, P.; Murugan, S.; Nagarajan, G. Dual fuel operation of Used Transformer Oil with acetylene in a DI diesel engine. Energy Convers. Manag. 2014, 87, 840-847. [CrossRef]

27. Prasanna, S.; Saravanan, C.G.; Kannan, M. Influence of injection timing on DI diesel engine characteristics fuelled with waste transformer oil. Alex. Eng. J. 2015, 54, 881-888.

28. International Standard Organization. ISO 3046 Reciprocating Internal Combustion Engines-Performance; International Standard Organization: Geneva, Switzerland, 1996.

29. Heywood, J.B. Internal Combustion Engine Fundamentals; McGraw-Hill Inc.: New York, NY, USA, 1988; pp. 509-510.

30. Heywood, J.B. Internal Combustion Engine Fundamental; McGraw Hill Publications: New York, NY, USA, 1988; pp. 491-667.

31. Raheman, H.; Prakash Jena, C.; Snehal, S.J. Performance of a diesel engine with blends of biodiesel (from a mixture of oils) and high speed diesel. Int. J. Energy Environ. 2013, 6, 1-9. [CrossRef]

32. Chauhan, B.S.; Kumar, N.; Cho, H.M. A study on the performance and emission of a diesel engine fuelled with Jatropha biodiesel oil and its blends. Energy 2012, 37, 616-622. [CrossRef]

33. Dhar, A.; Agarwal, A.K. Performance, emissions and combustion characteristics of Karanja biodiesel in a transportation engine. Fuel 2014, 119, 70-80. [CrossRef]

34. Hirkude, J.B.; Padalkar, A.S. Performance and emission analysis of acompression ignition: Engine operated on waste fried oil methyl esters. Appl. Energy 2012, 90, 68-72. [CrossRef]

35. Kakati, J.; Gogoi, T.K. Biodiesel production from Kutkura (Meyna spinosa Roxb. Ex.) fruit seed oil: Its characterization and engine performance evaluation with $10 \%$ and $20 \%$ blends. Energy Convers. Manag. 2016, 121, 152-161. [CrossRef]

36. Khiari, K.; Awad, S.; Loubar, K.; Tarabet, L.; Mahmoud, R.; Tazerout, M. Experimental investigation of Pistacialentiscus biodiesel as a fuel For directin injection diesel engine. Energy Convers. Manag. 2016, 108, 392-399. [CrossRef]

37. Lapuerta, M.; Jose, O.A.; Ferna'ndez, R. Effect of biodiesel fuels on diesel engine emissions. Prog. Energy Combust. Sci. 2008, 34, 198-223. [CrossRef] 
38. Ozsezen, A.N.; Canakci, M. Determination of performance and combustion characteristics of a diesel engine fueled with canola and waste palm oil methyl esters. Energy Convers. Manag. 2011, 52, 108-116. [CrossRef]

39. Usta, N. An experimental study on performance and exhaust emissions of a diesel engine fuelled with tobacco seed oil methyl ester. Energy Convers. Manag. 2005, 46, 2373-2386. [CrossRef]

40. Ong, H.C.; Masjuki, H.H.; Mahlia, T.M.I.; Silitonga, A.S.; Chong, W.T.; Leong, K.Y. Optimization of biodiesel production and engine performance from high free fatty acid Calophyllum inophyllum oil in CI diesel engine. Energy Convers. Manag. 2014, 81, 30-40. [CrossRef]

41. Chuah, L.F.; Rashid, A.; Aziz, A.; Yusup, S.; Bokhari, A.; Klemeš, J.J.; Abdullah, M.Z. Performance and emission of diesel engine fuelled by waste cooking oil methyl ester derived from palm oil using hydro dynamic cavitation. Clean Technol. Environ. Policy 2015, 15, 2229-2241. [CrossRef]

42. Raheman, H.; Ghadge, S.V. Performance of compression ignition engine with mahua (Madhuca indica) biodiesel. Fuel 2007, 86, 2568-2573. [CrossRef]

43. Gumus, M.; Kasifoglu, S. Performance and emission evaluation of a compression ignition engine using a biodiesel (apricot seed kernel oil methyl ester) and its blends with diesel fuel. Biomass Bioenergy 2010, 34, 134-139. [CrossRef]

(C) 2017 by the authors. Licensee MDPI, Basel, Switzerland. This article is an open access article distributed under the terms and conditions of the Creative Commons Attribution (CC BY) license (http://creativecommons.org/licenses/by/4.0/). 